\title{
BREAST CANCER IN WOMEN: RECURRENCE AND SURVIVAL AT FIVE YEARS
}

\author{
Valéria Costa Peres", Danyelle Lorrane Carneiro Veloso², Raphaela Maioni Xavier³, Ana Karina Marques \\ Salge ${ }^{4}$, Janaina Valadares Guimarães ${ }^{5}$
}

\footnotetext{
${ }^{1}$ M.Sc. in Nursing. Goiânia, Goiás, Brazil. E-mail: bahperes@hotmail.com

${ }^{2}$ M.Sc. in Nursing. Goiânia, Goiás, Brazil. E-mail: dany_lorrane@hotmail.com

${ }^{3}$ M.Sc. in Nursing. Goiânia, Goiás, Brazil. E-mail: raphinhaxis@gmail.com

${ }^{4}$ Ph.D. in Nursing. Professor at Faculdade de Enfermagem Universidade Federal de Goiás. Goiânia, Goiás, Brazil. E-mail: anakarina@ fen.ufg.br

${ }^{5}$ Ph.D. in Nursing. Professor at Faculdade de Enfermagem, Universidade Federal de Goiás. Goiânia, Goiás, Brazil. E-mail: valadaresjanaina@gmail.com
}

\begin{abstract}
Women undergoing breast cancer treatment are still at risk of recurrence. This study investigated the association among survival and relapse with staging of breast cancer in women treated in an oncology reference hospital in Goiânia-GO, Brazil over a five-year period after diagnosis in 2008. This descriptive, retrospective, cross-sectional study was conducted with the medical records of 460 women. Data were analyzed using Fisher's Exact Test and the Kaplan Meier Curve. Overall, mortality, local/regional recurrence and metastasis were at $14.1 \%, 6.5 \%$ and $25.2 \%$, respectively. There was an improvement in the survival of women with breast cancer at five years, but there is still a significant number of women diagnosed in advanced stages and experiencing recurrence, indicating there is a need to improve detection of the disease in its early stages and recurrences.
\end{abstract}

DESCRIPTORS: Breast neoplasms. Recurrence. Survivorship. Oncology nursing.

\section{CÂNCER DE MAMA EM MULHERES: RECIDIVA E SOBREVIDA EM CINCO ANOS}

RESUMO: As mulheres que realizam tratamento de câncer de mama ainda apresentam riscos de recorrência da doença. Objetivou-se verificar a associação entre sobrevida e recidiva com o estadiamento do câncer de mama em mulheres atendidas em um hospital de referência em Goiânia-GO cinco anos após o diagnóstico em 2008. Trata-se de um estudo de coorte, retrospectivo, descritivo constituído de prontuários de 460 mulheres. A análise dos dados foi realizada pelo Teste Exato de Fisher e Curva de Kaplan Meier. Do total, a taxa de óbito, recidiva local/regional e metástase foi de $14,1 \%, 6,5 \%$ e $25,2 \%$, respectivamente. Verificou-se uma melhora da sobrevida de mulheres com câncer de mama, porém ainda há um número considerável de mulheres sendo diagnosticadas em estádios avançados e que apresentam recidiva da doença, demonstrando a necessidade de melhora na detecção precoce do câncer em estádios iniciais e de casos de recidiva.

DESCRITORES: Neoplasias da mama. Recidiva. Sobrevida. Enfermagem oncológica.

\section{CÁNCER DE MAMA EN MUJERES: RECURRENCIA Y SUPERVIVENCIA EN CINCO AÑOS}

\begin{abstract}
RESUMEN: Las mujeres que realizan tratamiento de cáncer de mama todavía presentan un riesgo de recurrencia de la enfermedad. Este estudio tiene como objetivo verificar a asociación entre sobrevivencia e recurencia del cáncer de mama en las mujeres atendidas en un hospital de referencia en Goiânia-GO cinco años después de del diagnóstico en 2008. Este es un estudio de cohorte, retrospectivo, descriptivo constituido por los expedientes de 460 mujeres. Los datos fueron analizados utilizando la Prueba Exacta de Fisher y la Curva de Kaplan Meier. Del total, la tasa de mortalidad, recurrencia regional/local y metástasis fue de $14.1 \%, 6.5 \%$ y $25.2 \%$, respectivamente. Hubo una mejoría en la supervivencia de las mujeres con cáncer de mama, pero todavía existe un número considerable de mujeres que son diagnosticadas en estadios avanzados y que presentan recurrencia de la enfermedad, demostrando la necesidad de la detección precoz del cáncer en estadios iniciales y de casos de recurrencia.
\end{abstract}

DESCRIPTORES: Neoplasias de la mama. Recurrencia. Sobrevida. Enfermería oncológica. 


\section{INTRODUCTION}

Breast cancer is one of the most frequently diagnosed cancers among women and is the main cause of death due to cancer in this group, including women in developing countries. Survival in developing countries has been low, probably due to late diagnosis and limited access to appropriate care in some regions.

In Brazil, according to the National Institute of Cancer (INCA), when disregarding nonmelanoma skin cancer, breast cancer is the most incident among women with the exception of the North region, where the highest incidence is of cervical cancer. ${ }^{2}$ Estimates for 2012 indicated 53,000 new cases of female breast cancer in Brazil; there were 1,320 new cases in Goiás and 450 new cases in the city of Goiânia, GO, Brazil. ${ }^{3}$

Approximately $6.0 \%$ of breast cancers are metastatic at the time of the diagnosis, with a survival rate of $21.0 \%$ for a five-year period. The prevalence of metastasis is high because many women live with the disease for many years. Depending on the prognosis, relapse may occur in up to $30.0 \%$ of cases with negative lymph nodes and in approximately $70.0 \%$ of cases with positive lymph nodes. ${ }^{4}$

A study conducted in a population of 20,027 American women showed a recurrence rate of breast cancer up to the ten year point of $36.8 \%$, while most cases occurred in the first five years after diagnosis $(81.9 \%)$ and were related to advanced stage, neoplasias with poorly differentiated histological grades and hormone-receptor-negative. ${ }^{5}$

Studies addressing breast cancer patients cared for by INCA report an overall survival of $52.0 \%$ for five years. When relating staging to breast cancer survival, a survival rate of $80.0 \%$ is found for stages in situ and IIa; $70.0 \%$ for stage IIb, $50.0 \%$ for stage IIIa, $32.0 \%$ for stage $\mathrm{IIIb}$, and $5.0 \%$ for stage IV. This information corroborates the view that survival is strongly influenced by the extension of the disease at the time of the diagnosis, which can be assessed by tumor staging. ${ }^{6}$

It is important to describe breast cancer recurrence patterns in specific groups to identify the risk of these patients and improve survival rates with appropriate therapeutic approaches specific to each group. ${ }^{7}$ Hence, a regular description of data concerning breast cancer is essential to assessing the profile of women affected by this neoplasia and who are under treatment, as well as to assess the efficacy of strategies currently applied in regard to early detection, treatment and reduction of mortality rates due to breast cancer so that necessary strategies are either adapted or maintained to impact the health of women positively. Therefore, it is important to investigate the current situation of breast cancer recurrence and survival.

Based on the previous discussion, this study's objective was to verify association among survival, recurrence, and staging of breast cancer for women cared for in a hospital of excellence in oncological treatment in Goiania, capital of the state of Goiás, Brazil. This capital was selected for this study because a small number of recent studies addressing these variables were identified in this region.

\section{METHOD}

A cohort, cross-sectional, retrospective, and descriptive study was conducted using the medical records of women diagnosed with breast cancer in 2008 and cared for in the Araújo Jorge hospital, a hospital of excellence in oncological treatment in the city of Goiânia-GO, Brazil.

Data were collected between June and October 2013 using a semi-structured script and by analyzing the medical records of women cared for in 2008. The medical records were selected through an analysis of the facility's database. These files were selected according to the type of cancer and year in which diagnosis was established. The eligible medical files refer to patients diagnosed with primary breast cancer in 2008 and cared for in this same hospital, regardless of the health insurance used. A total of 470 medical files were identified; ten of these were excluded, as they were not available at the facility for consultation after three attempts. Hence, a total of 460 medical files were analyzed.

After data were collected from the medical files, an electronic script was filled out in which data were automatically transferred to an electronic spreadsheet generating the final database. After the treatment of data and automatic transference using Excel, data were analyzed using the Statistical Package for Social Science (SPSS 19.0).

In regard to the results, the categorical variables were presented as absolute values (f) and percentages (\%), and the continuous variables were presented with averages \pm standard 
deviations. Fisher's exact test was used to verify association among the variables' recurrence, death and staging. The Kaplan-Meier survival curve was used to identify the survival of women in a period of five years. A confidence level of $95 \%$ was considered for all the tests; that is, results were considered significant at $p<0.05$. The Institutional Review Board at Araújo Jorge Hospital - Association Against Cancer in Goiás approved the study with protocol No. 001/2013 and met the guidelines of Resolution 466/012.

\section{RESULTS}

A total of 460 medical files of women diagnosed with breast cancer in 2008 and cared for in the facility under study were included in the study. Most women (34.1\%) were diagnosed in stage III. In regard to locale of residence, $95.4 \%$ of the users cared for in the facility lived in cities in the interior of the state of Goiás, while $41.3 \%$ of the total lived in Goiânia at the time of their diagnosis.

The predominant age range of women was from 50 to 69 years old (47.8\%), with the exception of those cases diagnosed in stage IV, in which there was a predominance $(33.3 \%)$ of women in this stage aged between 35 and 49 years old. The age of the women participating in the study ranged from 24 to 91 years old, with an average age of 54.2 years old \pm 13.2 years.

In regard to the total population, married women $(54.3 \%)$ and those who self-reported as being Caucasian (63.3\%) predominated. The general characterization of the studied sample is presented in Table 1.

Table 1 - General characterization of the sample of women diagnosed with breast cancer receiving treatment in a hospital of excellence. GoiâniaGO, Brazil, 2008-2013

\begin{tabular}{lcc}
\hline \multirow{2}{*}{ Variables } & \multicolumn{2}{c}{ No. of cases $(\mathbf{n}=\mathbf{4 6 0})$} \\
\cline { 2 - 3 } & $\mathbf{f}$ & $\mathbf{\%}$ \\
\hline Marital Status & & \\
$\quad$ No partner/spouse & 195 & 42.4 \\
$\quad$ Partner/spouse & 265 & 57.6 \\
Race & & \\
$\quad$ Caucasian & 291 & 63.3 \\
$\quad$ Other & 169 & 36.7 \\
Locale of residence & & \\
$\quad$ Goiânia & 190 & 41.3 \\
$\quad$ Other & 270 & 58.7
\end{tabular}

Peres VC, Veloso DLC, Xavier RM, Salge AKM, Guimarães JV

\begin{tabular}{|c|c|c|}
\hline \multirow{2}{*}{ Variables } & \multicolumn{2}{|c|}{ No. of cases $(n=460)$} \\
\hline & $\mathbf{f}$ & $\%$ \\
\hline \multicolumn{3}{|l|}{ Retired } \\
\hline No & 320 & 69.4 \\
\hline Yes & 134 & 29.1 \\
\hline No information & 6 & 1.3 \\
\hline \multicolumn{3}{|l|}{ Occupation } \\
\hline Homemaker & 260 & 56.5 \\
\hline Other & 194 & 42.2 \\
\hline No information & 6 & 1.3 \\
\hline \multicolumn{3}{|l|}{ Health insurance } \\
\hline SUS & 300 & 65.2 \\
\hline Other & 154 & 33.5 \\
\hline No information & 6 & 1.3 \\
\hline \multicolumn{3}{|l|}{ Recurrence } \\
\hline Yes & 132 & 28.7 \\
\hline No & 213 & 46.3 \\
\hline No information & 115 & 25.0 \\
\hline \multicolumn{3}{|l|}{ Stopped follow-up } \\
\hline Yes & 121 & 26.3 \\
\hline No & 339 & 73.7 \\
\hline \multicolumn{3}{|l|}{ Staging } \\
\hline 0, I and II & 242 & 52.6 \\
\hline III and IV & 184 & 40.0 \\
\hline No information & 34 & 7.4 \\
\hline \multicolumn{3}{|l|}{ Death } \\
\hline Yes & 65 & 14.1 \\
\hline No & 212 & 46.1 \\
\hline No information & 183 & 39.8 \\
\hline
\end{tabular}

Thirty local and regional recurrences and 116 cases of distant metastasis were identified in the total population, resulting in an incidence rate of $6.5 \%$ and $25.2 \%$, respectively, for a period of five years. Of this total, 14 (3.0\%) women presented both local/regional recurrence and metastasis in the five-year period. A total of $65.5 \%$ of the women presented metastasis in one site. The sites to which metastasis more frequently spread were bones $(35.5 \%)$ and the lungs $(25.3 \%)$. More than half $(62.6 \%)$ of the cases of metastasis occurred in the first two years after diagnosis.

Among those who presented metastasis, 51 $(43.9 \%)$ died, as did eight $(26.6 \%)$ of those who presented local recurrence. No significant results were found when relating death to race $(p=0.334)$, marital status $(p=0.439)$ or age $(p=0.386)$.

Table 2 presents the relationship between recurrence and death and staging variables. Crosstabulation of the variables recurrence versus death showed that $252(54.8 \%)$ of the total medical files simultaneously contained information regarding both variables. 
Table 2 - Relationship of recurrence and death and staging. Goiânia-GO, Brazil, 2008-2013

\begin{tabular}{lrrrrl}
\hline \multirow{2}{*}{ Variables } & \multicolumn{4}{c}{ Recurrence } & \multirow{2}{*}{ p } \\
\cline { 2 - 5 } & \multicolumn{2}{c}{ No } & \multicolumn{2}{c}{ Yes } & \\
\hline Death & \multicolumn{1}{c}{ f } & \multicolumn{1}{c}{ f } & $\%$ & \\
No & 157 & 80.9 & 37 & 19.1 & \\
Yes & 4 & 6.9 & 54 & 93.1 & $<0.001^{*}$ \\
$\quad$ Total & 161 & 63.9 & 91 & 36.1 & \\
Staging & & & & & \\
$\quad$, I and II & 134 & 76.6 & 41 & 23.4 & \\
III and IV & 67 & 45.0 & 82 & 55.0 & $<0.001$ \\
$\quad$ Total & 201 & 62.0 & 123 & 38.0 & \\
* Fisher's exact test & & & &
\end{tabular}

Of the 460 medical files under study, $14.1 \%$ had death confirmed in the period since diagnosis. Of these, 34 (52.3\%) women died in the first two years after the diagnosis. Figure 1 shows the survival curve in the period of five years concerning the population under study.

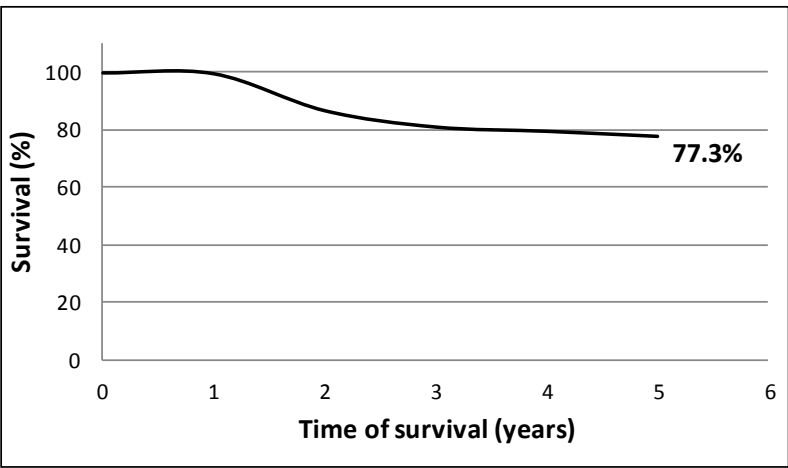

Figure 1 - Kaplan-Meier survival curve

To calculate the Kaplan-Meier survival curve, the date of diagnosis and date of death were taken into account. Of the 460 medical files, $183(39.8 \%)$ did not provide information concerning death and three did not report the date of diagnosis. Therefore, the curve was calculated using information from 274 patient files, out of which $62(22.7 \%)$ patients died and $212(77.3 \%)$ survived.

The highest occurrence of metastasis - 53 $(45.6 \%)$ women - as well as the highest occurrence of death - $33(50.7 \%)$ - was observed among women in stage III. Association between advanced stages at the time of diagnosis and the occurrence of metastasis in a five-year period was statistically significant $(p<0.05)$, as was the relationship between advanced staging and death within five years, as shown in Table 3.
Table 3 - Relationship between death and staging. Goiânia-GO, Brazil, 2008-2013

\begin{tabular}{|c|c|c|c|c|c|}
\hline \multirow{2}{*}{ Variables } & \multicolumn{4}{|c|}{ Death } & \multirow[b]{2}{*}{ p } \\
\hline & \multicolumn{2}{|c|}{ No } & \multicolumn{2}{|c|}{ Yes } & \\
\hline \multicolumn{6}{|l|}{ Staging } \\
\hline 0 , I and II & 122 & 87,8 & 17 & 12.2 & \multirow{3}{*}{$<0.001^{*}$} \\
\hline III and IV & 80 & 65.0 & 43 & 35.0 & \\
\hline Total & 202 & 77.1 & 60 & 22.9 & \\
\hline
\end{tabular}

Even though when relating death versus staging $262(56.9 \%)$ the files simultaneously showed information concerning both variables, 198 (43.0\%) files were considered a loss in this analysis as information was missing regarding one or both variables (Table 3).

\section{DISCUSSION}

This study's results are similar to those of other studies reporting a predominance of breast cancer diagnoses among Caucasian women. ${ }^{8-10}$ A percentage of $63.3 \%$ of Caucasian women was identified in this study, which is similar to information provided by the Brazilian Institute of Geography and Statistics (IBGE) regarding the Census in 2010, in which $47.7 \%$ of the population self-reported being Caucasian. ${ }^{11}$

According to statistics concerning female breast cancer provided by the American Cancer Society in the United States, various rates of incidence were identified according to race/ethnicity. The average incidence per year of female breast cancer was higher among non-Hispanic white women (125.4 cases per 100,000 women). ${ }^{12}$ A multi-center study conducted in the United States addressed 15,204 women with breast cancer across the entire country and reports that $82.0 \%$ of these were non-Hispanic white womem. ${ }^{13}$

Mortality rates also vary according to ethnicity; the annual rate was higher among Afro-descendant women (32.4 deaths per 100,000 women). The differences in survival rates according to race/ ethnicity reflect access to early diagnoses, tumor biology, and access to appropriate treatment. ${ }^{12}$ Disparities in access to health services may be related to socioeconomic factors of distinct races/ethnicities, which may reflect variations in the staging at the time of the diagnosis and prognosis among women of different races/ethnicities.

This study determined that the diagnosis of breast cancer predominated among women 
aged from 50 and 69 years old (47.8\%). Likewise, a study conducted in Florianópolis, SC, Brazil with 1,008 female breast cancer patients, reports a predominance in the age range between 50 and 69 years old $(28.8 \%)$ and a higher rate of survival among those aged between 40 and 49 years old. ${ }^{9}$ Similar results concerning the age range reported by different studies ${ }^{10}$ confirm the age range proposed by the Brazilian Ministry of Health to screen breast cancer. ${ }^{3}$

In this study, however, we identified a predominance of women aged between 35 and 49 years old $(33.3 \%)$ who were diagnosed in stage IV, which does not correspond to the screening proposal of the Ministry of Health that recommends a mammography every two years among women between 50 and 69 years of age. ${ }^{6}$ Even though the Ministry of Health recommends screening through clinical assessment to start at the age of 40 years old, there is a share of the population $(<40$ years old) who will not be screened routinely, except for those at a high risk of developing breast cancer, and who may be diagnosed in advanced stages and consequently, will have worse prognoses. Additionally, we have to consider that a long period is required from the time of onset up to the diagnosis of breast cancer, that is, for the tumor to reach $1 \mathrm{~cm}$ diameter, at which point it becomes palpable. ${ }^{6}$ If the cancer is not treated in this period, there is a greater probability of metastasis and death ${ }^{6}$ among women within the age range in question.

In this study we found that 265 (57.6\%) women reported having a partner/spouse at the time they registered in the facility. Studies show a greater occurrence of breast cancer among married women, from $64.9 \%$ to $67.0 \% .{ }^{14}$ A European study, conducted between 1997 and 2010, identified that marital status influenced both the recurrence and life expectancy of women with breast cancer, as psychosocial factors affect the development of metastasis and consequently, the survival of patients. Women who never married and widowed women aged from 40 to 50 years old were the most vulnerable to the disease, while the maximum positive influence was observed among women who had a partner/spouse and were in constant contact with family members. ${ }^{15}$

This study shows that the majority of women cared for in the hospital under study were originally from the state of Goiás; however, less than half $(41.3 \%)$ of the consultations were provided to women from the capital of the state, showing this facility is a reference for various locations. This hospital is a reference center in the treatment of cancer in the Midwest region and provides care to women from other Brazilian regions (4.5\%), as shown by this study's results.

It is important that health care institutions follow the rapidity with which new cases emerge, developing sufficient resources as required to establish diagnoses, and to provide treatment and follow-up. ${ }^{3}$ The effectiveness of the breast cancer treatment is very much influenced by access to the best therapy available, while the SUS has worked on improving access to diagnosis and treatment, in addition to proposing integrated services to provide appropriate care. ${ }^{16}$

In regard to the staging at the time of the diagnosis, this study's findings are similar to those reported in other places in Brazil, showing that a high number $(40.0 \%)$ of diagnoses are established when cancer is in advanced stages. A study conducted in the North of Minas Gerais with 288 medical files between 2006 and 2009 shows that $47.6 \%$ of the women were diagnosed in advanced stages (III or IV). ${ }^{17}$ Similarly, $51.9 \%$ of women from the interior of São Paulo diagnosed with breast cancer were in advanced stages of the disease. In Rio de Janeiro, this percentage was $51.0 \%$. These results show the need to reduce the rate of diagnoses in advanced stages by reducing the time required to establish diagnoses, and by providing access to timely screening and treatment. ${ }^{8}$

In regard to survival rates, this study identified that $77.3 \%$ of the population survived the five-year period. A study conducted in Paraíba, Brazil with 438 patients reported that $79.1 \%$ of the population survived five years. ${ }^{19}$ A similar result was reported by another study conducted in Florianópolis, in which 1,002 women with breast cancer presented an overall survival rate of $76.0 \%$ for five years. ${ }^{20}$

When considering the total percentage of overall survival in this study, higher rates of survival were observed among women diagnosed in the initial stages of the disease $(57.0 \%)$ when compared to those diagnosed in more advanced stages $(37.7 \%)$. One study conducted with data provided by hospital records from Santa Catarina, Brazil, shows that women diagnosed in stage I had greater overall survival at five years $(93.6 \%)$, while those diagnosed in stage IV presented the lowest overall survival at five years $(27.3 \%)$. The risk of death presented by women diagnosed in stage III was 7.18 times greater than for women di- 
agnosed in stage I, while the risk of death of those diagnosed in stage IV was 19.49 times greater. ${ }^{20}$

In this study, a survival rate of $46.7 \%$ was identified among women diagnosed in stage III and $25.9 \%$ among those in stage IV. One study conducted in Paraíba with 438 women with breast cancer reports that $36.7 \%$ of the diagnoses were in advanced stages (III or IV) and that staging determines the prognosis of patients, with survival rates of $65.7 \%$ in stage III and $52.6 \%$ in stage IV. ${ }^{19}$ Comparing the results of this study with those reported by other studies, we verify that there is a discrepancy of data among studies, as in this study we disregarded cases in which follow-up was interrupted or when death was not confirmed in the medical records.

Similar to this study's results in which 27 women $(23.2 \%)$ who developed metastasis survived the five-year period, an American study estimated a survival of $26.0 \%$ at five years, while from $20 \%$ to $50 \%$ of patients diagnosed with breast cancer may develop metastasis. Therefore, according to the authors of the aforementioned study, metastatic breast cancer still presents a poor prognosis. ${ }^{21}$

In regard to rates of metastasis and loco-regional recurrence, this study's findings show $25.2 \%$ and $6.5 \%$, respectively. After follow-up of 2,534 women with breast cancer in Poland for six years, $35.0 \%$ experienced metastasis, $14.0 \%$ loco-regional recurrence and $39.0 \%$ died..$^{22}$ This difference is due the fact that these women presented triple negative breast cancer, which has a worse diagnosis when compared to non-triple negative breast cancer, with high recurrence rates. ${ }^{23}$ The metastasis and recurrence rates found in this study were not categorized according to hormonal receptors.

This study's results show that $62.6 \%$ of the women experienced recurrence in the first two years after treatment. After an average of 17 months of follow-up, a study conducted in Lebanon found $25.3 \%$ experienced recurrence, while the most common sites of metastasis were the brain $(19.0 \%)$, lungs $(19.0 \%)$, and bones $(12.0 \%)$. The risk of recurrence reached 1.5 years and was almost null after three years. ${ }^{24}$ The period of highest risk of recurrence within the first three years after the primary treatment was identified by other researchers who also reported that the brain and lungs ( $15.0 \%$ and $14.0 \%$, respectively) are the most common sites for metastasis. ${ }^{22}$ In contrast, we verified in this study that bones and the lungs (35.5\% and $25.3 \%$, respectively) were the most common sites for recurrence.
A survival rate of $29.62 \%$ was found in this study, both for bone and lung metastasis. When monitoring 557 women with breast cancer metastasis in Pittsburgh, USA from 1999 to 2010, researchers found a survival rate of $27.7 \%$ at the end of the monitoring period. ${ }^{25}$ According to a study conducted with patients cared for by a Cancer Center and Oncology Institute in Warsaw, Poland, survival rates were different depending on the site of metastasis; shorter length of survival was observed in cases of liver metastasis (3.5 months) and higher survival for lung metastasis (9.8 months) and local recurrence (9 months). ${ }^{22}$

In this study, the highest occurrence of metastasis $(25.2 \%)$ in a five-year period was verified between 2008 and 2013 in Goiania-GO, compared with $10.20 \%$ for distance metastasis in the same city in the period from 1989 to $2003 .{ }^{26}$ This increase may be explained by technological advancements that facilitated the identification of breast cancer recurrence over the years. ${ }^{27}$

\section{CONCLUSIONS}

This study revealed a greater incidence of breast cancer among Caucasian women aged from 50 to 69 years old, which is in agreement with the coverage proposed for screening programs in Brazil and in some other countries. There was, however, an alarming result concerning the high number of women aged between 35 and 49 years old diagnosed in advanced stages of the disease, showing the need to improve early diagnosis in this age range with a consequent decrease in the mortality rate. Marital status did not appear to be related to the diagnosis but positively influenced coping.

A high rate of survival was observed among breast cancer patients in the five-year period and reaffirmed higher survival rates among women diagnosed in the initial stages of the disease, while survival rates decreased considerably among those who experience metastasis. This shows the importance of continually assessing and valuing early detection methods, appropriate treatment and continuous monitoring of potential recurrences in order to devise strategies and implement actions geared toward reducing mortality and improving the quality of life of women affected by breast cancer.

This study provides relevant information that enables assessing the profile of women receiving treatment in the region and verifying the ef- 
ficacy of the strategies currently applied in regard to early detection, treatment and survival of breast cancer patients, so that necessary procedures are either maintained or adapted to favor a positive impact on women's health.

The incidence of breast cancer has increased over the years, probably due to a higher number of diagnoses, greater coverage of the population, more advanced technology available, new lifestyles and population aging. It is, therefore, essential that health services be at the forefront of the fight against breast cancer, constantly proposing new technologies, improving treatment and diagnoses and, especially, eliminating regional disparities concerning care and access to health facilities. Additionally, it is important the population receive clear information in regard to the services' flowchart and which healthcare institutions the community should turn to in order to screen for the disease and bring about its early detection.

Some difficulties were faced when conducting the study, such as medical files lacking relevant information, incomplete records and unreadable content verified in the database. These factors show a need to sensitize and encourage the health staff to complete medical files carefully and include important data regarding the disease to support future studies that will eventually benefit the hospital, women's health and the community at large.

\section{REFERENCES}

1. Jemal A, Bray F, Center MM, Ferlay J, Ward E, Forman D. Global cancer statistics. CA Cancer J Clin. 2011 Mar-Abr; 61(2):69-90.

2. Ministério da Saúde (BR). Secretaria de Atenção à Saúde. Departamento de Atenção Básica. Controle dos cânceres do colo do útero e da mama. $2^{\mathrm{a}}$ ed. Brasília (DF): MS; 2013.

3. Ministério da Saúde (BR). Instituto Nacional de Câncer. Estimativas 2012: incidência de câncer no Brasil. Rio de Janeiro (RJ): INCA; 2011.

4. Cardoso F, Senkus-Konefka E, Fallowfield L, Costa A, Castiglione M. Locally recurrent or metastatic breast cancer: ESMO Clinical Practice Guidelines for diagnosis, treatment and follow-up. Ann Oncol. 2010 Mai; 21(5):15-9.

5. Cheng L, Swartz MD, Zhao H, Kapadia AS, Lai D, Rowan PJ, et al. Hazard of recurrence among women after primary breast cancer treatment - a 10-year follow-up using data from SEER-Medicare. Cancer Epidemiol Biomarkers Prev. 2012 Mai; 21(5):800-9.

6. Ministério da Saúde (BR). Instituto Nacional do Câncer. Ações de enfermagem para o controle do câncer: Uma proposta de integração ensino-serviço. Rio de Janeiro (RJ): INCA, 2008

7. Montagna E, Bagnardi V, Rotmensz N, Viale G, Renne G, Cancello G, et al. Breast cancer subtypes and outcome after local and regional relapse. Ann Oncol. 2012Feb; 23(2):324-31.

8. Rezende MCR, Koch HA, Figueiredo JA, Thuler LCS. Causas do retardo na confirmação diagnóstica de lesões mamárias em mulheres atendidas em um centro de referência do Sistema Único de Saúde no Rio de Janeiro. Rev Bras Ginecol Obstet. 2009 Fev; 31(2):75-81.

9. Schneider IJC, D'Orsi E. Sobrevida em cinco anos e fatores prognósticos em mulheres com câncer de mama em Santa Catarina, Brasil. Cad Saúde Pública. 2009 Jun; 25(6):1285-96.

10. Huguet PR, Morais SS, Osis MJD, Pinto-Neto AM, Gurgel MSC. Qualidade de vida e sexualidade de mulheres tratadas de câncer de mama. Rev Bras Ginecol Obstet [online]. 2009 Fev [acesso 2014 Jan 08]; 31(2):61-7. Disponível em: http:/ /www. scielo.br/scielo.php?script=sci_arttext\&pid=S010072032009000200003\&lng=en

11. Instituto Brasileiro de Geografia e Estatística (IBGE). Censo Demográfico 2010: características gerais da população, religião e pessoas com deficiência. Rio de Janeiro (RJ): IBGE; 2010.

12. DeSantis C, Siegel R, Bandi P, Jemal A. Breast cancer statistics, 2011. CA Cancer J Clin. 2011 NovDec;61(6):409-18.

13. Lin NU, Vanderplas A, Hughes ME, Theriault RL, Borda SB, Wong YN, et al. Clinicopathological features, patterns of recurrence, and survival among women with triple-negative breast cancer in the National Comprehensive Cancer Network. Cancer. 2012 Nov; 118(22):5463-72.

14. Bim CR, Pelloso SM, Carvalho MDB, Previdelli ITS. Diagnóstico precoce do câncer de mama e colo uterino em mulheres do município de Guarapuava, PR, Brasil. Rev Esc Enferm USP. 2010; 44(4):940-6.

15. Kuznecova G, Kuznecovs I, Kuznecovs S. Marital status of women renders an essential influence on occurrence of the relapses of disease and life expectancy of women with breast cancer. Eur J Cancer. 2012 Mar; 48(Supl1):s51.

16. Ministério da Saúde (BR). Instituto Nacional de Câncer José Alencar Gomes da Silva. Recomendações para redução da mortalidade por câncer de mama no Brasil: balanço 2012. Rio de Janeiro (RJ): INCA; 2012.

17. Soares PBM, Quirino Filho S, Souza WP, Gonçalves RCR, Martelli DB, Silveira MF et al. Características das mulheres com câncer de mama assistidas em serviços de referência do Norte de Minas Gerais. Rev Bras Epidemiol [online]. 2012 Set [acesso 2014 jan 07]; 15(3):595-604. Disponível em: http:/ / www. scielo.br/scielo.php?script=sci_arttext\&pid=S1415790X2012000300013\&lng=en 
18. Rodrigues JSM, Ferreira NMLA. Caracterização do perfil epidemiológico do câncer em uma cidade do interior paulista: conhecer para intervir. Rev Bras Cancerol. 2010; 56(4):431-41.

19. Basílio RLS. Sobrevida de mulheres portadoras de câncer de mama e fatores associados [dissertação]. Campina Grande (PB): Universidade Estadual da Paraíba; 2011.

20. Schneider IJC. Estudo de sobrevida em mulheres com câncer de mama em Santa Catarina [dissertação]. Florianópolis (SC): Universidade Federal de Santa Catarina; 2008.

21. Lu J, Steeg PS, Price JE, Krishnamurthy S, Mani SA, Reuben J, et al. Breast cancer metastasis: challenges and opportunities. Cancer Res. 2009 Jun; 69(12):49513.

22. Pogoda K, Niwińska A, Murawska M, Pieńkowski T. Analysis of pattern, time and risk factors influencing recurrence in triple-negative breast cancer patients. Med Oncol. 2013 Mar; 30(1):388.

23. Yagata H, Kajiura Y, Yamauchi H. Current strategy for triple-negative breast cancer: appropriate combination of surgery, radiation, and chemotherapy. Breast Cancer. 2011 Jul; 18(3):165-73.

24. Ghosn M, Hajj C, Kattan J, Farhat F, El Karak F, Nasr $\mathrm{F}$, et al. Triple-Negative Breast cancer in Lebanon: a case series. Oncologist. 2011;16(11):1552-6.

25. Jung SY, Rosenzweig M, Sereika SM, Linkov F, Brufsky A, Weissfeld JL. Factors associated with mortality after breast cancer metastasis. Cancer Causes Control. 2012 Jan; 23(1):103-12.

26. Nunes RD, Martins E, Freitas-Junior R, Curado MP, Freitas NMA, Oliveira JC. Estudo descritivo dos casos de câncer de mama em Goiânia, entre 1989 e 2003. Rev Col Bras Cir [online]. 2011 Ago [acesso 2014 Jan 10]; 38(4):212-6. Disponível em: http://www.scielo.br/scielo.php?script $=$ sci_ arttext\&pid=S0100-69912011000400002\&lng=en

27. Shulman LN, Willett W, Sievers A, Knaul FM. Breast cancer in developing countries: opportunities for improved survival. J Oncol. 2010;2010:595167. 